\title{
Morphological and molecular characterization of Stigonema jureiensis sp. nov. (Nostocales, Cyanobacteria) from the Atlantic Rainforest, São Paulo, Brazil
}

\author{
Guilherme S. HentschKe ${ }^{1}$, Janaína Rigonato ${ }^{2}$, Diego B. GenuÁrio ${ }^{3}$, Haywood \\ D. Laughinghouse $\mathrm{IV}^{4} \&$ Célia L. SANT'AnNA ${ }^{5}$
}

\author{
${ }^{I}$ Interdisciplinary Centre of Marine and Environmental Research - CIIMAR, Universidade do Porto, Av. General \\ Norton de Matos S/N, 4450-208, Matosinhos, Portugal; e-mail: guilherme.scotta@gmail.com \\ ${ }^{2}$ Department of Zoology and Botany, Instituto de Biociências, Letras e Ciências Exatas (UNESP), R. Cristóvão \\ Colombo, 2265, Jardim Nazareth, CEP 15054-000, São José do Rio Preto, SP, Brazil-Present address: CEA, \\ Centre de Sequençage Genoscope, Institut de Biologie François Jacob 91057 Évry, France \\ ${ }^{3}$ EMBRAPA Environment, Laboratory of Environmental Microbiology, 13820-000 Jaguariúna, SP, Brazil \\ ${ }^{4}$ Agronomy Department, Fort Lauderdale Research and Education Center, University of Florida / IFAS, 3205 \\ College Avenue, Davie, FL 33314, USA. \\ Institute of Botany, Laboratory of Phycology, Av. Miguel Stéfano, 3687, Água Funda, CEP 04301-902, São \\ Paulo, SP, Brazil
}

\begin{abstract}
Tropical regions are considered hotspots of biodiversity, and the genus Stigonema has been underexplored in all world, mainly due to the difficulties of culturing. In this study, we sequenced the 16S rRNA gene of a natural Stigonema population from the tropical Atlantic Rainforest (São Paulo, Brazil) and describe S. jureiensis sp. nov. based on phylogenetic and morphological data. For the molecular analysis, the genomic DNA was isolated from aliquots of the population, which were previously manually cleaned under a microscope, using a point-tapered Pasteur pipette to remove other organisms and debris. For morphological analysis, 30 individuals were analyzed and photographed using microscope. Both maximum likelihood and Bayesian phylogenies support S. jureiensis as a new species, and morphological analysis revealed the presence of a special type of mosaic ornate sheaths.
\end{abstract}

Key words: biodiversity, microorganism, polyphasic approach, taxonomy, terrestrial habitats, tropical environments

\section{INTRODUCTION}

The nostocalean genus Stigonema Bornet et Flahault is abundantly distributed worldwide, but phylogenetic studies on it are scarce compared to other cyanobacterial genera. This is mainly due to difficulties on isolating and culturing this taxon, and consequently, until recently, taxonomic studies on Stigonema were based solely on morphology. In a study on the diversity of true-branched Cyanobacteria from the Brazilian Atlantic Rainforest, FERREIRA et al. (2013) published the first combined molecular and morphological analysis of a Stigonema population (S. ocellatum Bornet et Flahault). Using the glass-capillary isolation technique, MAREš et al. (2015) were able to sequence the 16S rRNA gene of several morphologically characterized Stigonema presenting a robust $16 \mathrm{~S}$ rRNA gene phylogeny for the genus. In the same year, SoNG et al. (2015) described S. dinghuense SoNG et LI based on both morphological and molecular data. These two latter studies support the monophyly of the genus Stigonema.

After these initial publications, a large number of 16S rRNA gene sequences of Stigonema were deposited in public DNA sequence databases (GenBank). Thus, the current situation of the genus is: (1) there are 164 Stigonema 16S rRNA gene sequences in GenBank; (2) most of them are not associated to a published manuscript, thus lack morphological data; (3) there is a lack of information on 16S-23S rRNA Internal Transcribed Spacer (ITS) sequences and secondary structures; (4) as with other cyanobacteria, the infrageneric phylogenetic relationships are uncertain; and (5) there are few Stigonema strains in culture collections, making the access to the $16 \mathrm{~S}$ rRNA gene of these populations difficult. Thus, most of the taxonomic studies of Stigonema are restricted to morphological data presented in classic works, such as Bornet \& Flahault (1889), Gardner (1927), FrÉmy (1930), Geitler (1933), and KomÁreK (2013).

The genus Stigonema is abundant in the Brazilian Atlantic Rainforest, being studied by SiLva \& SANT'ANNA 
(1988), who described S. gracile Silva et Sant'Anna from Ilha do Cardoso (Atlantic Rainforest) and SILVA \& SANT'Anna (1996), who revised the genus for São Paulo State, Brazil. The most recent study on Stigonema from the Atlantic Rainforest described three new species and presented four other morphotypes commonly found in the biome (SANT'ANNA et al. 2013). Although there has been a large diversity of Stigonema reported for the Atlantic Rainforest, the genus is still poorly studied in this biome, with all papers, except for FERREIRA et al. (2013), restricted to morphological analysis.

In this study, we sequenced the 16S rRNA gene from a natural population of Stigonema collected in the Atlantic Rainforest (São Paulo State, Brazil). The population presented a unique type of mosaic-like sheath and based on both phylogenetic and morphological data, we describe and propose the new species, Stigonema jureiensis sp. nov.

\section{Material ANd Methods}

A Stigonema population was collected in August 2011 by scraping biofilms growing on an igneous rocks in the tropical

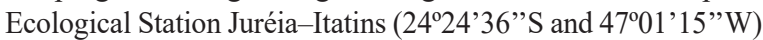
area of the Brazilian Atlantic Rainforest. The material was stored and dried using paper bags, and later in the laboratory the dried material was rehydrated for 20 hours in distilled water for morphological analysis. At least 30 individuals were analyzed and photographed using a Zeiss Axioplan 2 light microscope, equipped with a Zeiss Axiocam MRc digital camera. These images were compared to known Stigonema species in KомÁreк (2013). A subsample was preserved in formaldehyde $(4 \%)$ and deposited in the Herbarium of the Institute of Botany São Paulo, Brazil (SP), under the number SP 427311.

Subsequently to the morphological inspection, for the $16 \mathrm{~S}$ rRNA gene analysis, the natural population was cleaned using a point-tapered Pasteur pipette under a microscope to remove organisms and debris attached to the filaments. Afterwards, 50 individuals were transferred and washed sequentially into five new droplets of sterile distilled water. Total genomic DNA was extracted from these individuals using a DNeasy UltraClean Microbial Kit (Qiagen) and the 16S rRNA gene was amplified using the 27F and 1494Rc PCR primers (NEILAN et al. 1997). For amplification and sequencing of our material, we followed the methods in Fiore et al. (2007) and HentschKe et al. (2016). Phylogeny was inferred based on Maximum Likelihood (ML) and Bayesian (BA) trees, which were constructed in several steps (HentsChKe et al. 2016). To position our species in the Nostocales tree, first we aligned our sequence with sequences of Brasilonema Fiore et al., Calothrix Bornet et Flahault, Chlorogloeopsis Mitra et Pandey, Coleodesmium Geitler, Dapisostemon Hentschke et al., Hassallia Bornet et Flahault, Iphinoe Lamprinou et Pantazidou, Microchaete Bornet et Flahault, Petalonema Correns, Rivularia Bornet et Flahault, Scytonema Bornet et Flahault, and Tolypothrix Bornet et Flahault. Then, we added all Stigonema sequences used in the phylogeny of MAREŠ et al. (2015), plus other related sequences retrieved from GenBank using BLAST (total of 170 OTUs with 752 informative sites) (tree not shown). To obtain trees with a greater number of informative sites, higher bootstrap support, and to eliminate polytomies, we excluded all identical sequences and all sequences with less than 1297 nucleotides length. In order to study our populations at the species level, we constructed trees using only those Stigonema sequences associated to articles with morphological data. To do this, we searched GenBank for the publications of all 164 Stigonema sequences available on 08 March 2019. Then, we selected the published sequences, excluded the clones, and performed the alignment for phylogenetic analysis.

For all generated trees, the sequences were aligned using ClustalW and the GTR $+\mathrm{G}+\mathrm{I}$ evolutionary model was selected by running Modeltest in MEGA 7.0 (Kumar et al. 2016). The robustness of ML trees was estimated by bootstrap, using 1000 replications in MEGA 7.0 (KuMAR et al. 2016). The Bayesian trees were constructed in two independent runs, with four chains each for $5 \times 10^{5}$ generations, using Mr. Bayes (RoNQUisT \& HUEKSENBECK 2003). The outgroups used were Gloeobacter violaceus AF132791, Chroococcidiopsis sp. FR798923 and Chroococcidiopsis sp. AB039005.

A similarity matrix ( $\mathrm{p}$-distance) was also generated to compare Stigonema jureiensis with the closest phylogenetically related taxa. The $16 \mathrm{~S}$ rRNA gene sequence of $S$. jureiensis was deposited in GenBank (NCBI) under the accession Uncultured Stigonema JUR147 (MK471331).

\section{RESULTS}

While studying the cyanobacterial flora of tropical and subtropical areas of the Atlantic Rainforest (São Paulo, Brazil), an interesting new terrestrial stigonematacean taxon was observed. The taxon fit very well into the morphological circumscription of Stigonema, featuring true branches (T-type) and multiseriate trichomes. However, it differed from all the currently described species of Stigonema, due to unique mosaic-like sheaths that had not been previously described for the genus (Figs 1-7). Thus, we propose a new species, Stigonema jureiensis sp. nov., supported by morphological and molecular data.

The first step of the 16S rRNA gene phylogeny (total of 170 OTUs with 752 informative sites) confirmed that our proposed new species was placed in the strongly supported Stigonema clade (ML $=100 \%$, BA = 1) (tree not shown). In the second step, the ML and BA trees (63 OTUs with 1325 informative sites) showed similar topology, presenting two main clades with strong phylogenetic support (Fig. 8). In the basal position of Nostocales, the cluster containing Brasilonema, Chlorogloeopsis, Iphinoe, Rivularia, and Scytonema $(\mathrm{ML}=$ $32 \%, \mathrm{BA}=0.99)$ is sister to the cluster of Coleodesmium, Dapisostemon, Hassallia, and Stigonema (ML = 99\%, $\mathrm{BA}=1.0)$. Although Stigonema is monophyletic (ML $=99 \%, \mathrm{BA}=1.0)$, the relationships among its species are unresolved. In the Stigonema clade, the uni- and multiseriate species are intermixed (Fig. 8). Furthermore, some infrageneric clades were common by different species with strong phylogenetic support.These were the cases of $S$. spectabile KT867140 (multiseriate) and S. elegans KT867212 (uniseriate), which are in the same clade with ML support of $100 \%$ and BA of 1.0; the clade of S. cornutum KT867200 and S. turfaceum KT867159 
$(\mathrm{ML}=96 \%, \mathrm{BA}=1.0) ;$ S. cornutum $\mathrm{KT} 867201$ and $S$. lechangense $\mathrm{KT} 867217(\mathrm{ML}=98 \%, \mathrm{BA}=1.0)$; and $S$. intermedium KT867215 and S. fragile KT867160 (ML $=88 \%, \mathrm{BA}=1.0$ ). It is also important to highlight that strains of $S$. anomalum Blanchard, S. cornutum Gardner, S. elegans Gardner, $S$. hormoides Bornet et Flahault, $S$. ocellatum Bornet et Flahault, and S. panniforme Bornet et Flahault were found in more than one clade. In this tree, $S$. jureiensis is a unique branch separated from other Stigonema species.

In order to connect morphological and phylogenetic data, the third step of the ML and BA trees (Fig 9) were built only with strains that contained published morphological data. In these trees, $S$. jureiensis formed again a unique branch separated from other Stigonema species, and it was sister to $S$. hormoides and $S$. tomentosum Hieronymus $(\mathrm{ML}=85 \%, \mathrm{BA}=0.98)$. The similarity ( $\mathrm{p}$-distance) values between $S$. jureiensis and these strains range from 97\% with S. hormoides KM047007 to $99.5 \%$ with $S$. tomentosum KM047014.

\section{Species Description}

Stigonema jureiensis G. S. Hentschke et C. L. Sant'Anna sp. nov. (Figs 1-7)

Filaments forming a felt-like thallus, erect, more or less parallel, tortuous 23-33 $\mu \mathrm{m}$ diam., sometimes slightly tapered from the base towards the ends, intensely branched.
Branches identical to the main filament, bending toward the apex. Sheaths massive, hyaline, yellowish, mosaiclike sculptured with irregular margins. Trichomes with uni- and multiseriate parts 16-25 $\mu \mathrm{m}$ diam, composed by dark-green compressed or spherical cells, 5-11 $\mu \mathrm{m}$ diameter. Apex rounded, usually uniseriate, slightly tapered or not. Heterocytes lateral, irregulary sphaerical.

Holotype: BRAZIL, São Paulo State, Ecological Station Juréia-Itatins, sampled 08/16/2011by Guilherme S. Hentschke, Watson A. Gama Jr., Camila F. S. Malone and Célia L. Sant'Anna. Fixed sample (SP 427311) deposited in Herbarium of São Paulo State, São Paulo, Brazil.

Type locality: Atlantic Rainforest, Ecological Station Juréia-Itatins $\left(24^{\circ} 24^{\prime} 36^{\prime \prime S}, 4^{\circ} 01^{\prime} 15^{\prime \prime W}\right)$, São Paulo State, Brazil.

Reference sequence: Uncultured Stigonema sp. JUR147 (NCBI Accession number: MK471331).

Habitat: On a humid igneous rock in a dense rainforest area. Etymology: The name is after the Ecological Station Juréia-Itatins.

\section{Discussion}

Although Stigonema jureiensis shares high similarity (p-distance 99.5\%) with S. tomentosum KM047014, both

Table 1. Morphological comparisons among S. jureiensis and related species.

\begin{tabular}{|c|c|c|c|}
\hline & $\begin{array}{l}\text { S. mamilosum Bornet et Fla- } \\
\text { hault (KoMÁREK 2013) }\end{array}$ & $\begin{array}{l}\text { S. tomentosum Hieronymus } \\
\text { (KoMÁREK 2013) }\end{array}$ & S. jureiensis sp. nov. \\
\hline Thallus & $\begin{array}{l}\text { Sessile, pillow-like or forming } \\
\text { filamentous clusters. Dark brown } \\
\text { or greenish brown }\end{array}$ & Felt-like, tufty. & Felt-like \\
\hline Filaments & $\begin{array}{l}\text { Multiseriate, heteropolar, richly } \\
\text { branched. Up to 65(90) } \mu \mathrm{m} \text { di- } \\
\text { ameter. }\end{array}$ & $\begin{array}{l}\text { Uniseriate (in some parts } 2 \text { cells), } \\
\text { creeping, branched, } 14-28(38) \mu \mathrm{m} \\
\text { diameter. }\end{array}$ & $\begin{array}{l}\text { Uni to multiseriate, erect, }+- \\
\text { parallel, tortuous, } 23-33 \mu \mathrm{m} \\
\text { diameter., sometimes slightly } \\
\text { tapered from the base towards } \\
\text { the ends, intensely branched. }\end{array}$ \\
\hline Branches & With perpendicular hormogonia. & $\begin{array}{l}\text { Erect, uniseriate, commonly in } \\
\text { fascicles, with the same diameter } \\
\text { of the main filament or slightly } \\
\text { narrower. }\end{array}$ & $\begin{array}{l}\text { Branches identical to the main } \\
\text { filament, bending toward the } \\
\text { apex. }\end{array}$ \\
\hline Cells & $\begin{array}{l}\text { Sphaerical or irregulary sphaeri- } \\
\text { cal }\end{array}$ & $\begin{array}{l}\text { Barrel-shaped, often with indi- } \\
\text { vidual envelopes. }\end{array}$ & Compressed or sphaerical cells. \\
\hline Heterocytes & Lateral & Intercalary & Lateral \\
\hline Sheaths & Colourless or yellow, lamellated. & $\begin{array}{l}\text { Narrow, lamellated, yellow- } \\
\text { brown. }\end{array}$ & $\begin{array}{l}\text { Sheaths abundant, hyaline or } \\
\text { yellowish, mosaic-like sculp- } \\
\text { tured with irregular margins. }\end{array}$ \\
\hline Habitat & $\begin{array}{l}\text { Aquatic, submersed, benthic, on } \\
\text { stony substrates. }\end{array}$ & $\begin{array}{l}\text { Subaerophytic on wet wood and } \\
\text { rocks. }\end{array}$ & $\begin{array}{l}\text { Aerophitic, on an igneous rock } \\
\text { in the Atlantic rainforest. }\end{array}$ \\
\hline
\end{tabular}



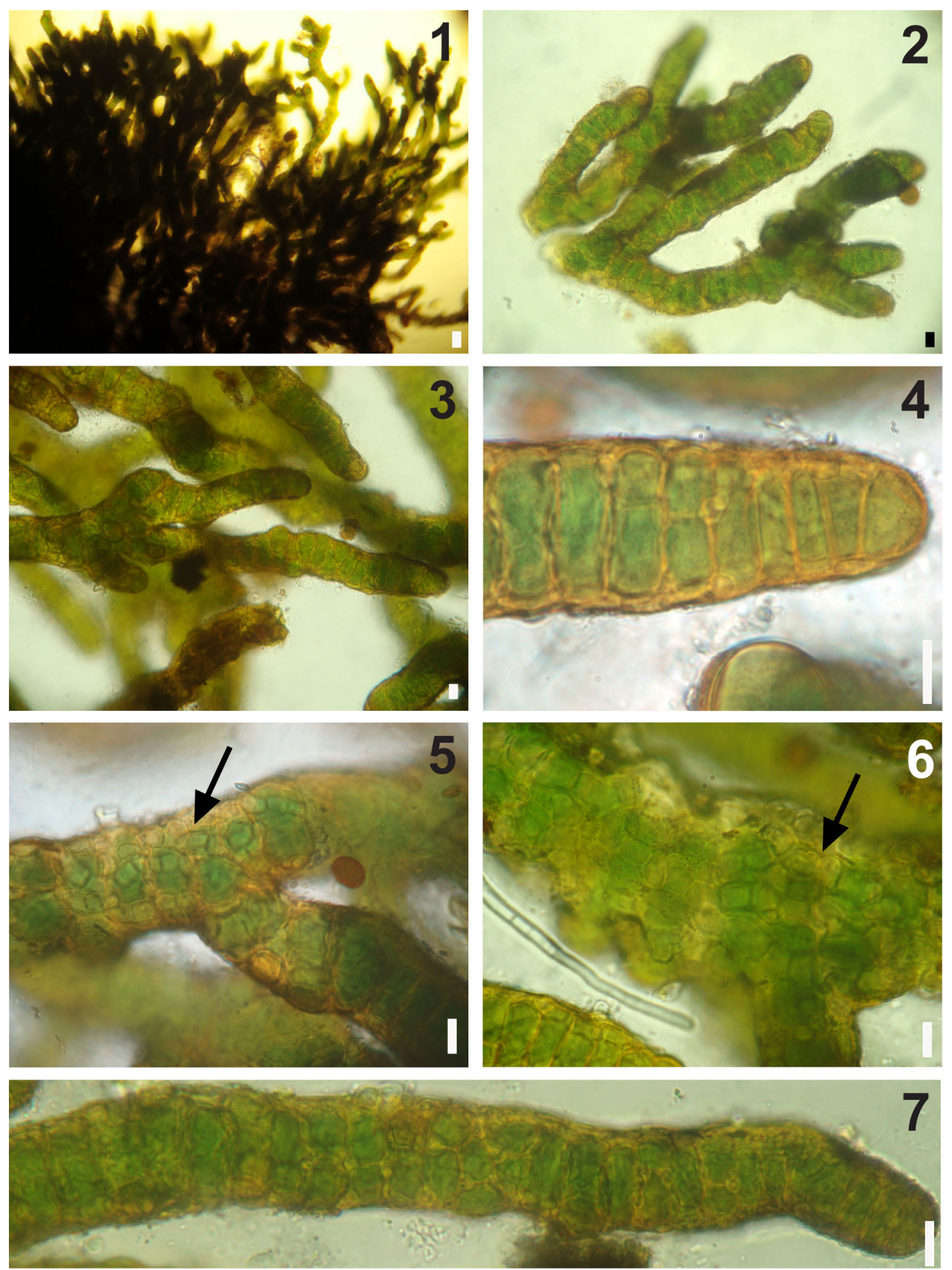

Figs 1-7. Stigonema jureiensis: (1-3) General view of the thallus; (4) Detail of rounded filament end; (5) Details of a branch tapered at the base and the mosaic-like sheaths; (6) Mosaic-like sheaths; (7) Filament with uni- and polyseriate parts. Scale bars $50 \mu \mathrm{m}(1), 10 \mu \mathrm{m}(2-7)$. Arrows indicate the details of mosaic-like sheaths.

species are morphologically distinct. S. tomentosum is uniseriate and has lamellate sheaths, while $S$. jureiensis is multiseriate and has a unique type of mosaic sculptured sheaths, making the new species morphologically distinct from any other species of the genus (Table 1). This hypothetical genetic relationship was very likely influenced by the relatively short length of S. tomentosum KM047014 sequence (1075 bp), and the low number of informative sites in the phylogenetic analysis (965 bp). Also, our phylogenies show that $S$. jureiensis is separated from other species within the Stigonema clade. Thus, we propose and describe our novel species following criteria 


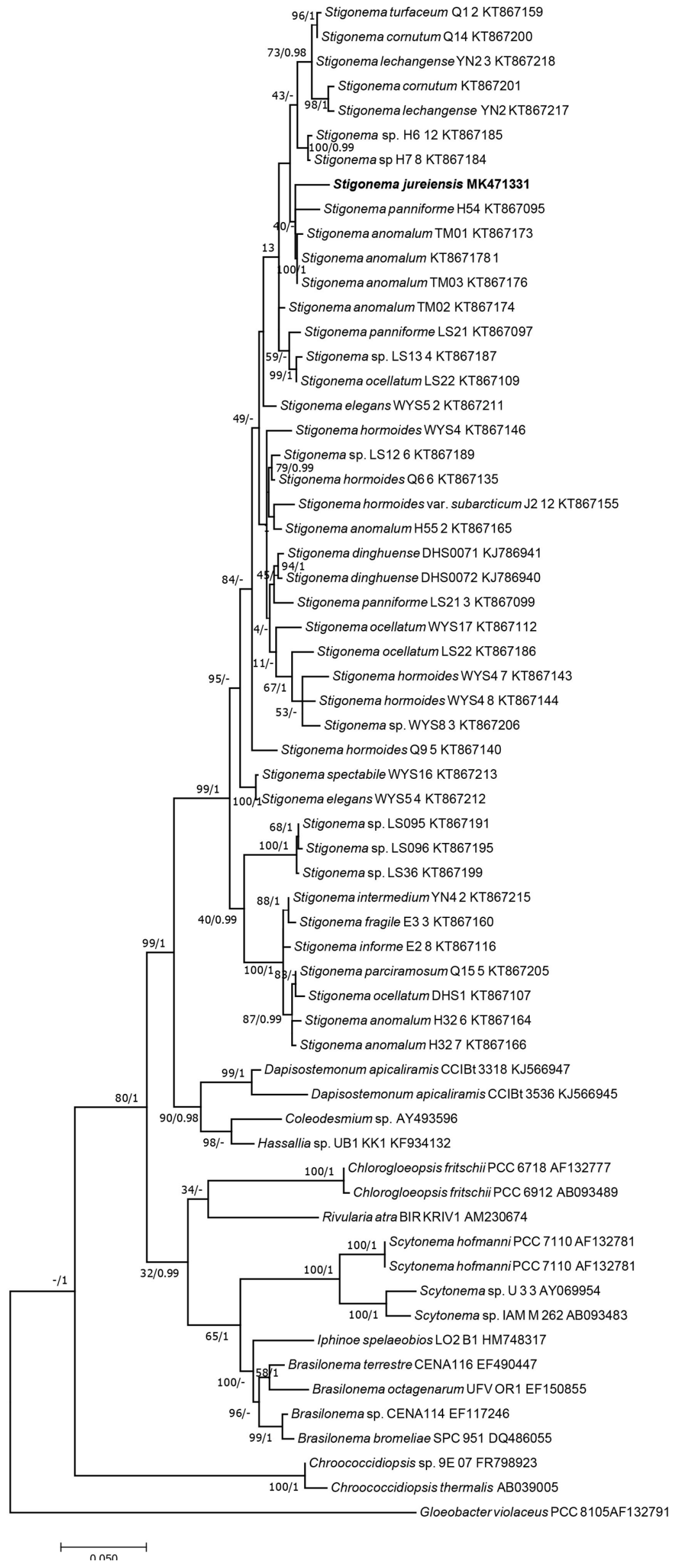

Fig. 8. Molecular phylogenetic analysis by Maximum Likelihood method. Bootstrap values and probabilities (ML/BA) are indicated at nodes. The analysis involved 62 nucleotide sequences and there were a total of 1325 informative sites in the final dataset. - =no support. 


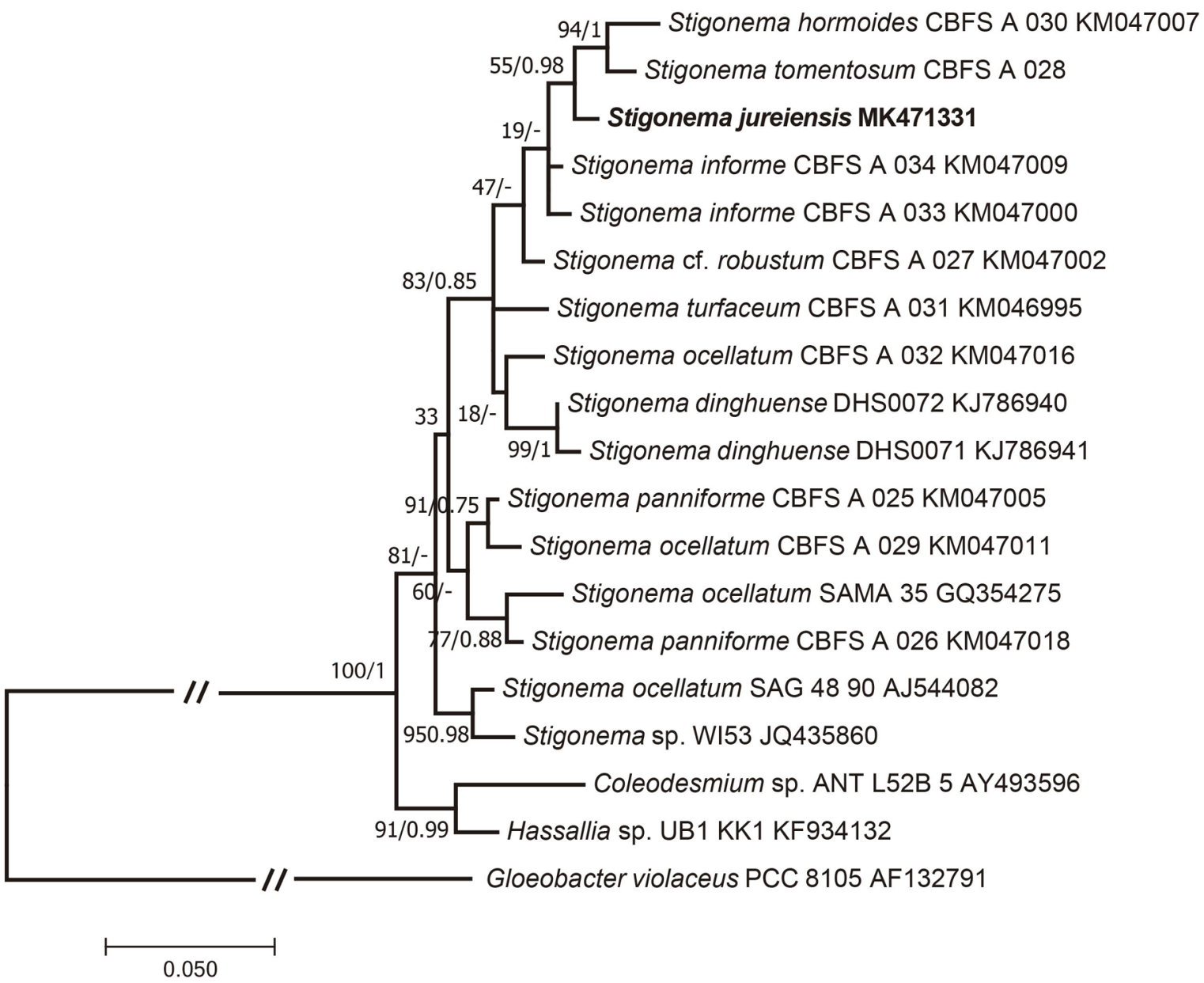

Fig. 9. Molecular Phylogenetic analysis by Maximum Likelihood method. Bootstrap values ML/BA are indicated at nodes. All populations in these trees are morphologically analyzed and published in previous papers. Bootstrap values and probabilities (ML/BA) are indicated at nodes. The analysis involved 19 nucleotide sequences and there were a total of 964 informative sites in the final dataset. - =no support.

outlined in JOHANSEN \& CASAMATTA (2005). Our results agree with the first criterion of new species description presented by the authors, which requires evidence of genetic separation to existing species. The mosaic-sculptured sheaths are a strong evidence of genetic separation. Our results also follow the authors' second criterion, with $S$. jureiensis separated from other phylogenetic clades. According to those, the morphological feature of $S$. jureiensis can be used to separate the species, and reinforces the phylogenetic data, strongly indicating that our population is a new species of Stigonema. The special kind of sheath in $S$. jureienesis has previously been described in Brasilonema ornatum Sant'Anna et al., Scytonema santannae Hentschke et Komárek and S. stuposum Bornet et Flahault (HentschKe \& KomÁreK 2014; SANT'AnNA et al. 2011) from the Brazilian Atlantic Rainforest, but was never reported for stigonematacean taxa. Up to now, all the cyanobacterial populations with mosaic-sculptured sheaths were found growing with fungal hyphae (HENTSCHKE \& KoMÁREK 2014), but we did not observe this for $S$. jureiensis. Probably, this character evolved independently in different lineages as an adaptation to the harsh conditions found in this environment such as high temperature and herbivory. In addition to the description of $S$. jureiensis, we corroborate previous studies (MAREŠ et al. 2015; SoNG et al. 2015) showing that uni- and multiseriate species of Stigonema are intermixed in phylogenies. These characters have most likely arisen more than once in the genus Stigonema. Our phylogenies also highlight the problem of species delimitation in Cyanobacteria, since the same species is found in more than one clade (i.e. Stigonema hormoides and S. ocellatum). In this case we agree with MAREŠ et al. (2015) that molecular and ecological divergent populations of these morphospecies will likely be further separated with more molecular data.

We also found that different morphospecies are grouped in monophyletic clades, as for example, the multiseriate $S$. spectabile WYS16 and the uniseriate $S$. elegans WYS54 $(\mathrm{ML}=100 \%, \mathrm{BA}=1.0)$. Considering the species concept of MisHLER \& THERIOT (2000), adapted by JOHANSEN \& CASAMATTA (2005), which states that species should be "monophyletic clusters of strains or natural populations that are diagnosable by some unique combination of traits, those traits being any combination of morphological, biochemical, molecular, or other 
characteristics", we think that in our trees, the clustering of different morphospecies in monophyletic clades is primarily due to the poor resolution of the $16 \mathrm{~S}$ rRNA gene at the species level and also by the scarce number of available 16S sequences of Stigonema populations. Other factors that negatively influence species delimitations in Stigonema are that most of the sequences of morphologically studied Stigonema populations are short, causing polytomies in phylogenies (MAREŠ et al. 2015; SoNG et al. 2015), and that there is a lack of $16 \mathrm{~S}-23 \mathrm{~S}$ rRNA ITS data. The longer and more useful Stigonema sequences in GenBank are from populations that have not yet been published, thus cannot be used in deeper discussions of species delimitations.

\section{CONCLUSION}

In this paper, we propose a new species Stigonema jureiensis, and conclude that the delimitations of species of Stigonema remain unclear. The current lack of ecological and morphological data from morphotypes which have sequences available in GenBank coupled with the short sequences from those morphologically well-studied, make the discussion at the species level difficult. Also, access to more molecular markers, such as the $16 \mathrm{~S}-23 \mathrm{~S}$ rRNA ITS is urgently needed to improve the resolution of monophyletic clades in the genus.

\section{ACKNOWLEDGEMENTS}

Guilherme Scotta Hentschke thanks to CNPq and FCT (UID/ Multi/04423/2019) for the financial support, and also thanks to Luís Henrique Zanini Branco for sharing laboratory facilities for molecular analysis. Diego Bonaldo Genuário was supported by a post-doctoral (2014/26131-7) fellowship funded by FAPESP.

\section{REFERENCES}

Altschul, S. F.; Gish, W.; Miller, W.; Myers, E. W. \& Lipman, D. J. (1990): Basic local alignment search tool. - Journal of Molecular Biology 215: 403-410.

Bornet, É. \& Flahault, C. (1889): Sur quelques plantes vivants dans le test calcaire des mollusques. - Bulletin de la Société Botanique de France 36: 147-167.

FERreira, V.; Branco, L. H. Z. \& KašTovskÝ, J. (2013): True branched nostocalean cyanobacteria from tropical aerophytic habitats and molecular assessment of two species from field samples. - Revista de Biologia Tropical 61: 455-466.

Fiore, M.F.; Sant'Anna, C. L.; Azevedo, M.T.P.; KomáreK, J.; KAŠTovsKÝ, J.; SULEK, J. \& LoRENZI, A.S. (2007): The cyanobacterial genus Brasilonema - molecular and phenotype evaluation. - Journal of Phycology 43: 789-798.

FrÉMY, P. (1930): Les Myxophycées de l'Afrique équatoriale française. - Archives de Botanique 3: 1-508.

GARDNER, N. L. (1927): New Myxophyceae from Porto Rico. - 150pp., New York Botanical Garden. New York.

GeITLER, L. (1932): Cyanophyceae. - In: KolKwItz, R. (ed.): Kryptogamenflora von Deutschland, Öesterreich und der Scheiz. - 1196 pp., Akademische Verlagsgesselsehaft,
Leipzig.

Hentschke, G. S.; Johansen, J. R.; Pietrasiak, N.; Fiore, M. F.; Rigonato, J.; Sant'Anna, C. L. \& Komárek, J. (2016): Phylogenetic placement of Dapisostemon gen. nov. and Streptostemon, two tropical heterocytous genera (Cyanobacteria). - Phytotaxa 245: 129-143.

HentschKe, G. S. \& KomÁReK, J. (2014): Scytonema santannae, a new morphospecies of Cyanobacteria from the Atlantic rainforest, southeastern Brazil. - Brazilian Journal of Botany 37: 293-298.

JOHANSEN, J.R. \& CASAMATTA, D.A. (2005): Recognizing cyanobacterial diversity through adoption of a new species paradigm. - Algological Studies 117: 71-93.

KoMÁREK, J. (2013): Cyanoprokaryota. 3rd part: Heterocytous Genera - In: BüDEL, B.; GärTNER, G.; KRIENITZ, L. \& SCHAGERL, H. (eds): Süßwasserflora von Mitteleuropa, Bd. 19/3. - 1131pp., Springer. Zurich.

Kumar, S.; Stecher, G. \& TAMURA, K. (2016): MEGA7: Molecular Evolutionary Genetics Analysis Version 7.0 for Bigger Datasets. - Molecular Biology and Evolution 33:1870-4.

MAREŠ, J.; LARA, Y.; DADÁKová, I.; HAUER, T.; Uher, B.; WiLmotte, A. \& KaštovskÝ J. (2015): Phylogenetic analysis of cultivation-resistant terrestrial cyanobacteria with massive sheaths (Stigonema spp. and Petalonema alatum, Nostocales, Cyanobacteria) using single-cell and filament sequencing of environmental samples. Journal of Phycology 51: 288-297.

Mishler, B.D. \& Theriot, E C. (2000): The phylogenetic species concept (sensu MisHLER and THERIOT): monophyly, apomorphy, and phylogenetic species concepts. - In: WheELER Q.D. \& MEIER R. (eds): Species concepts and phylogenetic theory, a debate. - p. 44-54, Columbia University Press, New York.

Neilan, B. A.; Jacobs, D.; Dot, T. D.; Blackall, L. L.; Hawkins, P. R.; Cox, P. T. \& Goodman, A. R. (1997): rRNA sequences and evolutionary relationships among toxic and nontoxic cyanobacteria of the genus Microcystis. - International Journal of Systematic and Evolutionary Microbiology 47: 693-697.

Ronquist, F. \& HuELSENBECK, J. P. (2003): MRBAYES 3: Bayesian phylogenetic inference under mixed models. - Bioinformatics 19:1572-1574.

Sant'Anna, C. L.; Azevedo, M. T. P.; Fiore, M.; Lorenzi, A.; KAŠTovsKÝ, J. \& KoMÁREK, J. (2011): Subgeneric diversity of Brasilonema (Cyanobacteria, Scytonemataceae). - Brazilian Journal of Botany 34: 51-62.

SANT'AnNa, C. L.; KaštovskÝ, J.; HentschKe, G. S. \& KomÁreK, J. (2013): Phenotypic studies on terrestrial stigonematacean Cyanobacteria from the Atlantic Rainforest, São Paulo State, Brazil. - Phytotaxa 89: 1-23.

Silva, S. M. F. \& SAnt'AnNa, C. L. (1988): Stigonema gracile sp. nov., a new taxon of Stigonemataceae (Cyanophyceae) from Brazil. - Revista Brasileira de Biologia 48: 391-395.

Silva, S. M. F. \& SANT'AnNA, C. L. (1996): Stigonemataceae (Cyanophyceae, Stigonematales) do Estado de São Paulo, Brasil: gênero Stigonema Bornet \& FlaHAULT. - Hoehnea: 23: 27-52.

Song, G.; XIANG, X.; Wang, Z. \& LI, R. (2015): Polyphasic characterization of Stigonema dinghuense, sp. nov. (Cyanophyceae, Nostocophycidae, Stigonemaceae), from Dinghu Mountain, south China. - Phytotaxa 213: 212-224.

(C) Czech Phycological Society (2019)

Received April 15, 2019

Accepted June 18, 2019 